\title{
Assessment of Malocclusion in school children of Karnataka State between the age groups of 10-12 years and 13-16 years. A Cross- sectional Descriptive Survey.
}

\author{
Dr. Roopa Siddegowda ${ }^{1}$, Dr. Rani M.S ${ }^{2}$ \\ ${ }^{1}$ (Department of Orthodontics, Vokkaligara Sangha Dental College \& Hospital/ Rajiv Gandhi University of \\ Health Sciences, India) \\ ${ }_{2}^{2}$ (Department of Orthodontics, Vokkaligara Sangha Dental College \& Hospital/ Rajiv Gandhi University of \\ Health Sciences, India)
}

\begin{abstract}
Context: Malocclusion can compromise the oral health tissues and can lead to social and psychological problem. Hence an investigation of the malocclusion status at the developing stages of the dentitions to intercept the same is required. Aims: To assess the malocclusion in school children of Karnataka between the age groups of 10-12 years and 13-16 years. Settings and Design: School settings and Descriptive cross-sectional survey. Methods and Material: A cross-sectional epidemiological survey was conducted in all the 30 districts of Karnataka. School children in the age group of 10-16 years were the target population. Population proportionate technique was employed for the sample size estimation. A total sample of 9505 was randomly selected from 102 schools all over Karnataka. Ackermann-Proffit classification of malocclusion was used to record the malocclusion. Statistical analysis used: Simple Descriptive statistics. Results and Conclusion: Prevalence of crowding is $52.3 \%$ in mixed dentition and $50.2 \%$ in permanent dentition. Cross-bite was reported in $17.4 \%$ and $18.3 \%$ in mixed and permanent dentition respectively. Increased over-jet was reported in $15.3 \%$ and $7.7 \%$ in mixed and permanent dentitions respectively.
\end{abstract}

Keywords: Prevalence, Malocclusion, School children, 10-12 years, 13-16 years, Ackermann-profit system.

\section{INTRODUCTION}

Age is the main determinant for progress of any disease. In context to the specialty of Pedodontics and Orthodontics, some developing malocclusions may get self corrected with the progress of age. The assessment and correction of developing and established malocclusion is an important facet of the specialty of Orthodontics. Prevalence of malocclusion is largely varied in the Indian children due to limitations in sample selection and methodology, lack of uniform criteria in recording malocclusion and its traits, reliability and consistency of recording by the same or different field workers and ethnic differences. ${ }^{1}$ In Indian, studies on prevalence of malocclusion have shown wide variation from $19.6 \%{ }^{2}$ to $96.05 \%{ }^{3}$. Karnataka is a vast state in India constituting 30 districts. The state covers $5.83 \%$ of the total geographical area of India. Few prevalence studies on malocclusion are reported. ${ }^{4,5,6}$ According to the World Health Organization, the main oral diseases should be subjected to periodic epidemiological surveys. It is necessary to carry out epidemiologic studies of malocclusion in all regions at different age groups to grade the severity of malocclusion according to the respective age groups. With this background we undertook a survey to assess the malocclusion in school children of Karnataka state between the age groups of 10-12 years and 13-16 years.

\section{1, Objective of the study:}

To assess malocclusion in school children of Karnataka state between the age groups of 10-12 years and 13-16 years.

\section{2, Materials and Methodology:}

With a prior permission from the Ministry of Higher Primary and Secondary Education Board of Karnataka, a cross-sectional epidemiological survey was conducted in the State of Karnataka. The survey was carried out in selected schools in all the district head quarters. Children in the age group of 10-16 years were included in the study and constituted the study population. Population proportionate technique was employed for sample size estimation. According to the population census 2011, the total population in Karnataka is 6,11,30,704, out of which 10-16 years old children constitute 29\% (According to National Family Health Survey-2, India [1998-99], child population in the age group of 10-16 years was taken as a reference). With $95 \%$ confidence level, the estimated sample size was 9505. In the first stage of sampling, three categories of schools, namely, Government schools, Aided schools, and Private schools in each district were selected from a list of schools provided by the Karnataka Higher Primary and Secondary Education Board by lottery method. In the 
second stage, 102 schools all over Karnataka were surveyed during the year 2012. All children in the age group of 10-16 years, from the selected schools in each district all over Karnataka and children who obtained written informed consent from parents to participate in the study were included. Exclusion criteria used were- history of previous orthodontic treatment, rampant caries, multiple missing teeth, mutilated malocclusion and other craniofacial anomalies like cleft lip and palate, facial hemiatropy, cleidocranial dysplasia etc.

Ethical clearance to conduct the survey was obtained from the Institutional Review Board (Vokkaligara Sangha Dental College and Hospital). Prior permission to conduct the survey was taken from the concerned school authorities. A written informed consent was obtained from the parents of the children to conduct the survey.

The oral examination was done in day light using mouth mirror and dental probe. The observations were recorded in the assessment form and later transferred to the PC. Ackermann-Proffit ${ }^{7}$ classification of malocclusion was used to record the malocclusion. The Dental Health check-up was done for the remaining children and an oral health education lecture was given to all the children in the school to create awareness about Dental health and Orthodontic treatment.

\section{Ackermann-Proffit system of classification of Malocclusion}

The description of the criterias in each of these categories are as follows:

1. Alignment-
i. Midline --
0 -Midlines coinciding,
$1-<$ half the lower incisor width,
2- $>$ half the lower incisor width.
ii. Spacing---
0- Absent,
1- Midline diastema,
2- Anterior spacing,
3- Generalized spacing
iii. Crowding---
0 - Absent,
1- Anterior crowding [a] Mild ,[b] Moderate, [c] Severe,
2- Posterior crowding
iv. Protrusion of teeth---
0 - Absent
1- Protrusion of upper teeth,
2- Protrusion of lower teeth,
3- Protrusion of both upper and lower teeth
v. Retrusion of teeth---
0 - Absent
1-Retrusion of upper teeth,
2- Retrusion of lower teeth,
4- Retrusion of both upper and lower teeth.

2. Skeletal deviations -

i. Profile---

1-Straight profile,

2-Anterior divergent,

3-Posterior divergent,

4-Convex profile,

5-Concave profile

ii. Maxillary position---

0 -Normal maxilla,

1-Prognathic maxilla,

2-Retrognathic maxilla

iii. Mandibular position---

0 -Normal mandible,

1-Prognathic mandible,

2-Retrognathic mandible. 
3. Transverse deviation-

i. Crossbite-- 0-No crossbite,

1-Single tooth crossbite,

2-Two or more teeth crossbite,

3-Anterior teeth crossbite,

4-Posterior Unilateral crossbite,

5-Posterior Bilateral crossbite.

4. Anteroposterior deviations-

i. Molar relation---1-Class I,

2-Class II [a] div1 [b] div2 [c]subdivision,

3- Class III [a]sub division.

ii. Overjet--- 1-Normal overjet[1-3mm],

2-Moderate overjet[3-5mm],

3 -Increased overjet $[>6 \mathrm{~mm}]$,

4-Reduced overjet $[<1 \mathrm{~mm}]$,

5 -Reverse overjet.

5. Vertical deviations-

i. Overbite---1- $1 / 3^{\text {rd }}$ of lower incisor overlap,

$2-2 / 3^{\text {rd }}$ of lower incisor overlap,

3- Completely locked lower incisors,

4-Edge to edge bite.

ii. Openbite--- 0-Openbite absent,

1-Open bite $<2 \mathrm{~mm}$,

2- Open bite $>4 \mathrm{~mm}$.

\section{3, Statistical analysis:}

Data were coded and entered into excel sheet. To maintain the data quality (validity) rechecking and cross checking were done during data entry phase. Later, data were transformed into SPSS windows version 16, where cleaning, coding, recording, crosschecking, processing and analysis of the data were done. Simple Descriptive statistics was applied to describe the study variables.

\section{Section1: Alignment discrepancies.}

\section{Results}

$33.3 \%$ of subjects in the age group of $10-12$ years and $33.4 \%$ of subjects in the age group of $13-16$ years had midline discrepancy as shown in Table 1. Midline diastema was observed in $7.8 \%$ of $10-12$ year children and $4.8 \%$ of $13-16$ year children (Table 2). Mild to moderate crowding was observed in $37.8 \%$ of subjects $10-12$ years and $25.8 \%$ of subjects in $13-16$ years and severe crowding was reported in $7.1 \%$ and $7.6 \%$ in 10-12 years and 13-16 years of children respectively as shown in Table 3. Protrusion of both upper and lower teeth was observed in $30 \%$ of $10-12$ years and $26.9 \%$ in $13-16$ years of children (Table 4). Retrusion of upper and lower teeth were $10.6 \%$ and $11.3 \%$ in $10-12$ years and $13-16$ years respectively (Table 5 ).

\section{Section 2: Antero-posterior deviations}

The prevalence of Angle Class I, Class II and Class III molar relations were $79.7 \%, 20.3 \%$ and $0.1 \%$ in the children of age group 10-12 years. In children of $13-16$ years age group $78.8 \%, 21.1 \%$ and $0 \%$ were the prevalence of Class I, Class II and Class III molar relations respectively as shown in Table 6. Increased over-jet was observed in $26.3 \%$ of $10-12$ years and $27.4 \%$ of $13-16$ years children as shown on Table 7 .

\section{Section 3: Transverse discrepancy}

Cross-bite was reported in $17.5 \%$ of children of $10-12$ years and $18.2 \%$ of children of $13-16$ years as shown in Table 8.

\section{Section 4: Vertical discrepancy}

Increased overbite was reported in $56.6 \%$ of $10-12$ year children and $56.3 \%$ of children with $13-16$ years as represented in Table 9. Open-bite of $1.9 \%$ in $10-12$ years and $4.4 \%$ in $13-16$ years of children was observed (Table 10). 


\section{Section 4: Skeletal deviations}

$67.1 \%$ of convex profile and $0.5 \%$ of concave profile was seen in $10-12$ years of children. $66.7 \%$ and $0.6 \%$ were the convex and concave profile respectively in the children of 13-16 years which is represented in Table 11. Maxilla was prognathic in $4.9 \%$ and retrognathic in $1.1 \%$ of children with $10-12$ years and $5 \%$ prognathic and $1.5 \%$ retrognathic in children of $13-16$ years age group (Table 12). Mandible was prognathic in $0.6 \%$ and retrognathic in $52.8 \%$ in children of $10-12$ years and prognathic in $0.8 \%$ and retrognathic in $53.3 \%$ of children in 13-16 years children as shown in Table 13.

Table 1- Frequency of Midline discrepancy in the age groups

\begin{tabular}{|l|l|r|r|r|c|}
\hline \multirow{2}{*}{ AGE GROUPS } & & \multicolumn{3}{|c|}{ MIDLINE } & \multirow{2}{*}{ Total } \\
\cline { 3 - 6 } & & Co-inciding & $\begin{array}{c}<\mathbf{1} / \mathbf{2} \text { Lower } \\
\text { Incisor width }\end{array}$ & $\begin{array}{c}>\text { Lower } \\
\text { Incisor width }\end{array}$ \\
\hline 10-12 years & F\&\% & $2871(66.7 \%)$ & $1166(27.1 \%)$ & $265(6.2 \%)$ & $4302(100.0 \%)$ \\
\hline 13-16 years & F\&\% & $3467(66.6 \%)$ & $1371(26.4 \%)$ & $365(7.0 \%)$ & $5203(100.0 \%)$ \\
\hline Total & F\&\% & $6338(66.7 \%)$ & $2537(26.7 \%)$ & $630(6.6 \%)$ & $\mathbf{9 5 0 5 ( 1 0 0 . 0 \% )}$ \\
\hline
\end{tabular}

Contingency Coefficient $=.018, \mathrm{P}$ value $=.212$

Table 2- Frequency of Spacing in the age groups

\begin{tabular}{|c|c|c|c|c|c|c|}
\hline \multirow{2}{*}{$\begin{array}{l}\text { AGE } \\
\text { GROUPS }\end{array}$} & & \multicolumn{4}{|c|}{ SPACING } & \multirow[t]{2}{*}{ Total } \\
\hline & & Absent & Diastema & $\begin{array}{l}\text { Anterior } \\
\text { spacing }\end{array}$ & $\begin{array}{c}\text { Generalized } \\
\text { spacing }\end{array}$ & \\
\hline 10-12 years & F\&\% & $3583(83.3 \%)$ & $337(7.8 \%)$ & $346(8.0 \%)$ & $36(.8 \%)$ & $4302(100.0 \%)$ \\
\hline 13-16 years & F\&\% & $4524(86.9 \%)$ & $250(4.8 \%)$ & $380(7.3 \%)$ & $49(.9 \%)$ & $5203(100.0 \%)$ \\
\hline Total & F\&\% & $8107(85.3 \%)$ & $587(6.2 \%)$ & $726(7.6 \%)$ & $85(.9 \%)$ & $9505(100.0 \%)$ \\
\hline
\end{tabular}

Contingency Coefficient $=.065, \mathrm{P}$ value $=.000$ (HS)

Table 3- Frequency of Crowding

\begin{tabular}{|c|c|c|c|c|c|c|c|}
\hline \multirow{2}{*}{$\begin{array}{l}\text { AGE } \\
\text { GROUPS }\end{array}$} & & \multicolumn{5}{|c|}{ CROWDING } & \multirow[t]{2}{*}{ Total } \\
\hline & & Absent & Mild & Moderate & Severe & Posterior & \\
\hline $\begin{array}{l}10-12 \\
\text { years }\end{array}$ & F\&\% & $2069(48.1 \%)$ & $861(20.0 \%)$ & $766(17.8 \%)$ & $305(7.1 \%)$ & $301(7.0 \%)$ & $\begin{array}{l}4302 \\
(100.0 \%)\end{array}$ \\
\hline Total & F\&\% & $4668(49.1 \%)$ & $1883(16.9 \%)$ & $1608(16.9 \%)$ & $702(7.4 \%)$ & $644(6.8 \%)$ & $9505(100.0 \%)$ \\
\hline
\end{tabular}

Contingency Coefficient $=.027, \mathrm{P}$ value $=.137$

Table 4- Protrusion of the upper and lower teeth

\begin{tabular}{|c|c|c|c|c|c|c|}
\hline \multirow{2}{*}{$\begin{array}{l}\text { AGE } \\
\text { GROUPS }\end{array}$} & & \multicolumn{4}{|c|}{ PROTRUSION } & \multirow[t]{2}{*}{ Total } \\
\hline & & Absent & Upper teeth & Lower teeth & Both & \\
\hline $10-12$ years & F\&\% & $2266(52.7 \%)$ & $1275(29.6 \%)$ & $20(.5 \%)$ & $741(17.2 \%)$ & $4302(100.0 \%)$ \\
\hline 13-16 years & F\&\% & $2669(51.3 \%)$ & $1374(26.4 \%)$ & $25(.5 \%)$ & $1135(21.8 \%)$ & $5203(100.0 \%)$ \\
\hline Total & F\&\% & $4935(51.9 \%)$ & $2649(27.9 \%)$ & $45(.5 \%)$ & $1876(19.7 \%)$ & $9505(100.0 \%$ \\
\hline
\end{tabular}

Contingency Coefficient $=.060, \mathrm{P}$ value $=.000(\mathrm{HS})$

Table 5- Retrusion of the upper and lower teeth Contingency Coefficient $=.034, \mathrm{P}$ value $=.011$

\begin{tabular}{|l|l|r|r|r|r|r|}
\hline \multirow{2}{*}{ AGE GROUPS } & & \multicolumn{4}{|c|}{ RETRUSION } & \multirow{2}{*}{ Total } \\
\cline { 3 - 6 } & & Absent & Upper teeth & \multicolumn{1}{c|}{ Lower teeth } & \multicolumn{1}{l|}{ Both } & \\
\hline $\mathbf{1 0 - 1 2}$ years & F\&\% & $3821(88.8 \%)$ & $453(10.5 \%)$ & $6(.1 \%)$ & $22(.5 \%)$ & $4302(100.0 \%)$ \\
\hline $\mathbf{1 3 - 1 6}$ years & F\&\% & $4576(87.9 \%)$ & $561(10.8 \%)$ & $24(.5 \%)$ & $42(.8 \%)$ & $5203(100.0 \%)$ \\
\hline Total & F\&\% & $\mathbf{8 3 9 7}(\mathbf{8 8 . 3} \%)$ & $\mathbf{1 0 1 4}(\mathbf{1 0 . 7} \%)$ & $\mathbf{3 0}(.3 \%)$ & $\mathbf{6 4}(.7 \%)$ & $\mathbf{9 5 0 5}(\mathbf{1 0 0 . 0} \%)$ \\
\hline
\end{tabular}

Table 6- Frequency of Molar relation

\begin{tabular}{|c|c|c|c|c|c|c|c|}
\hline \multirow{2}{*}{$\begin{array}{c}\text { AGE } \\
\text { GROUPS }\end{array}$} & & \multicolumn{5}{|c|}{ ANGLE'S MOLAR RELATION } & \multirow[t]{2}{*}{ Total } \\
\hline & & ClassI & ClassII Division1 & $\begin{array}{c}\text { ClassII } \\
\text { Division2 }\end{array}$ & $\begin{array}{c}\text { ClassII } \\
\text { Subdivision }\end{array}$ & ClassIII & \\
\hline 10-12years & F\&\% & $\begin{array}{c}3430(79.7 \% \\
)\end{array}$ & $559(13.0 \%)$ & $170(4.0 \%)$ & $140(3.3 \%)$ & $3(.1 \%)$ & $\begin{array}{c}4302 \\
(100.0 \%)\end{array}$ \\
\hline 13-16years & F\&\% & $\begin{array}{c}4100(78.8 \% \\
)\end{array}$ & $705(13.5 \%)$ & $205(3.9 \%)$ & $191(3.7 \%)$ & $2(.0 \%)$ & $\begin{array}{c}5203 \\
(100.0 \%)\end{array}$ \\
\hline
\end{tabular}

Contingency Coefficient $=.016, \mathrm{P}$ value $=.659$ 
Assessment of Malocclusion in school children of Karnataka State between the age groups of 10-12

Table 7- Frequency of Overjet

\begin{tabular}{|c|c|c|c|c|c|c|c|}
\hline \multirow[t]{2}{*}{ AGE GROUPS } & & \multicolumn{5}{|c|}{ OVERJET } & \multirow[t]{2}{*}{ Total } \\
\hline & & Normal & Moderate & Increased & Reduced & Reverse & \\
\hline $10-12$ years & F\&\% & $2657(61.8 \%)$ & $874(20.3 \%)$ & $260(6.0 \%)$ & $459(10.7 \%)$ & $52(1.2 \%)$ & $4302(100.0 \%)$ \\
\hline 13-16 years & F\&\% & $3099(59.6 \%)$ & $1087(20.9 \%)$ & $338(6.5 \%)$ & $623(12.0 \%)$ & $56(1.1 \%)$ & $5203(100.0 \%)$ \\
\hline Total & F\&\% & $5756(60.6 \%)$ & $1961(20.6 \%)$ & $598(6.3 \%)$ & $1082(11.4 \%)$ & $108(1.1 \%)$ & $9505(100.0 \%)$ \\
\hline
\end{tabular}

Contingency Coefficient $=.019, \mathrm{P}$ value $=.467$

Table 8- Frequency of Cross-bite

\begin{tabular}{|c|c|c|c|c|c|c|c|c|}
\hline \multirow{2}{*}{$\begin{array}{l}\text { AGE } \\
\text { GROUPS }\end{array}$} & & \multicolumn{6}{|c|}{ CROSSBITE } & \multirow[t]{2}{*}{ Total } \\
\hline & & Absent & $\begin{array}{c}\text { Single } \\
\text { tooth }\end{array}$ & $\begin{array}{c}\text { Two or } \\
\text { more } \\
\text { teeth }\end{array}$ & $\begin{array}{c}\text { Anterior } \\
\text { teeth }\end{array}$ & $\begin{array}{l}\text { Posterior } \\
\text { unilateral }\end{array}$ & $\begin{array}{l}\text { Posterior } \\
\text { bilateral }\end{array}$ & \\
\hline $\begin{array}{l}10-12 \\
\text { years }\end{array}$ & $\begin{array}{l}\text { F\& } \\
\%\end{array}$ & $3544(82.4 \%)$ & $514(11.9 \%)$ & $147(3.4 \%)$ & $58(1.3 \%)$ & $25(.6 \%)$ & $14(.3 \%)$ & $4302(100.0 \%)$ \\
\hline $\begin{array}{l}13-16 \\
\text { years }\end{array}$ & $\begin{array}{l}\text { F\& } \\
\%\end{array}$ & $4253(81.7 \%)$ & $659(12.7 \%)$ & $174(3.3 \%)$ & $59(1.1 \%)$ & $46(.9 \%)$ & $12(.2 \%)$ & $5203(100.0 \%)$ \\
\hline Total & $\begin{array}{l}\text { F\& } \\
\%\end{array}$ & $7797(82.0 \%)$ & $\begin{array}{l}1173(12.3 \\
\%\end{array}$ & $321(3.4 \%)$ & $117(1.2 \%)$ & $71(.7 \%)$ & $26(.3 \%)$ & $9505(100.0 \%)$ \\
\hline
\end{tabular}

Contingency Coefficient $=.024, \mathrm{P}$ value $=.338$

Table 9- Frequency of Overbite

\begin{tabular}{|l|l|c|c|c|c|c|}
\hline \multirow{2}{*}{$\begin{array}{l}\text { AGE } \\
\text { GROUPS }\end{array}$} & \multicolumn{4}{|c|}{ OVERBITE } & \multirow{2}{*}{ Total } \\
\cline { 2 - 7 } & $\begin{array}{c}\text { Overlapping } \\
\mathbf{1} / \mathbf{3} \text { the Lower } \\
\text { Incisor }\end{array}$ & $\begin{array}{c}\text { Overlapping } \\
\text { 2/3 the Lower } \\
\text { Incisor }\end{array}$ & $\begin{array}{c}\text { Complete } \\
\text { overlap }\end{array}$ & Edge to Edge & \\
\hline $\mathbf{1 0 - 1 2}$ years & $\mathbf{F \& \%}$ & $1601(37.2 \%)$ & $1831(42.6 \%)$ & $602(14.0 \%)$ & $268(6.2 \%)$ & $4302(100.0 \%)$ \\
\hline $\mathbf{1 3 - 1 6}$ years & $\mathbf{F \& \%}$ & $1901(36.5 \%)$ & $2109(40.5 \%)$ & $820(15.8 \%)$ & $373(7.2 \%)$ & $5203(100.0 \%)$ \\
\hline Total & F\&\% & $\mathbf{3 5 0 2 ( 3 6 . 8 \% )}$ & $\mathbf{3 9 4 0}(\mathbf{4 1 . 5 \% )}$ & $\mathbf{1 4 2 2 ( 1 5 . 0 \% )}$ & $\mathbf{6 4 1 ( 6 . 7 \% )}$ & $\mathbf{9 5 0 5}(\mathbf{1 0 0 . 0} \%)$ \\
\hline
\end{tabular}

Contingency Coefficient $=.033, \mathrm{P}$ value $=.014$

Table 10- Frequency of Openbite

\begin{tabular}{|l|c|c|c|c|c|}
\hline \multirow{2}{*}{ AGE GROUPS } & & \multicolumn{3}{|c|}{ OPENBITE } & \multirow{2}{*}{ Total } \\
\cline { 3 - 5 } & & Absent & $<\mathbf{m m}$ & $>\mathbf{4 m m}$ & \\
\hline $\mathbf{1 0 - 1 2}$ years & F\&\% & $4177(97.1 \%)$ & $57(1.3 \%)$ & $68(1.6 \%)$ & $4302(100.0 \%)$ \\
\hline $\mathbf{1 3 - 1 6}$ years & F\&\% & $5037(96.8 \%)$ & $93(1.8 \%)$ & $73(1.4 \%)$ & $5203(100.0 \%)$ \\
\hline Total & F\&\% & $\mathbf{9 2 1 4}(\mathbf{9 6 . 9 \%} \%)$ & $\mathbf{1 5 0}(\mathbf{1 . 6 \%})$ & $\mathbf{1 4 1}(\mathbf{1 . 5} \%)$ & $\mathbf{9 5 0 5}(\mathbf{1 0 0 . 0} \%)$ \\
\hline
\end{tabular}

Contingency Coefficient $=.020, \mathrm{P}$ value $=.156$

Table 11- Frequency of Profile

\begin{tabular}{|l|c|r|r|r|r|r|r|}
\hline \multirow{2}{*}{$\begin{array}{c}\text { AGE } \\
\text { GROUPS }\end{array}$} & & \multicolumn{5}{|c|}{ PROFILE } & \multirow{2}{*}{ Total } \\
\cline { 3 - 8 } & Straight & $\begin{array}{c}\text { Anterior } \\
\text { divergent }\end{array}$ & $\begin{array}{c}\text { Posterior } \\
\text { divergent }\end{array}$ & Convex & Concave & \\
\hline $\mathbf{1 0 - 1 2}$ years & F\&\% & $1392(32.4 \%)$ & $1(.0 \%)$ & $0(.0 \%)$ & $2887(67.1 \%)$ & $22(.5 \%)$ & $4302(100.0 \%)$ \\
\hline 13-16 years & F\&\% & $1697(32.6 \%)$ & $3(.1 \%)$ & $2(.0 \%)$ & $3471(66.7 \%)$ & $30(.6 \%)$ & $5203(100.0 \%)$ \\
\hline Total & F\&\% & $\mathbf{3 0 8 9}(\mathbf{3 2 . 5} \%)$ & $\mathbf{4 ( . 0 \% )}$ & $\mathbf{2 ( . 0 \% )}$ & $\mathbf{6 3 5 8}(\mathbf{6 6 . 9} \%)$ & $\mathbf{5 2 ( . 5 \% )}$ & $\mathbf{9 5 0 5}(\mathbf{1 0 0 . 0} \%)$ \\
\hline
\end{tabular}

Contingency Coefficient $=.046, \mathrm{P}$ value $=.001$

Table 12- Skeletal deviations of Maxilla

\begin{tabular}{|l|c|c|c|r|c|}
\hline \multirow{2}{*}{ AGE GROUPS } & \multirow{3}{*}{ MAXILLA } & \multirow{2}{*}{ Total } \\
\cline { 3 - 5 } & & Normal & Prognathic & \multicolumn{1}{|c|}{ Retrognathic } & \\
\hline 10-12 years & F\&\% & $4044(94.0 \%)$ & $211(4.9 \%)$ & $47(1.1 \%)$ & $4302(100.0 \%)$ \\
\hline 13-16 years & F\&\% & $4861(93.4 \%)$ & $262(5.0 \%)$ & $80(1.5 \%)$ & $5203(100.0 \%)$ \\
\hline Total & F\&\% & $\mathbf{8 9 0 5}(\mathbf{9 3 . 7} \%)$ & $\mathbf{4 7 3 ( 5 . 0 \% )}$ & $\mathbf{1 2 7}(1.3 \%)$ & $\mathbf{9 5 0 5 ( 1 0 0 . 0 \% )}$ \\
\hline
\end{tabular}

Contingency Coefficient $=.020, \mathrm{P}$ value $=.161$

Table 13- Skeletal deviations of Mandible

\begin{tabular}{|l|c|c|c|c|c|}
\hline \multirow{2}{*}{ AGE GROUPS } & & \multicolumn{3}{|c|}{ MANDIBLE } & \multirow{2}{*}{ Total } \\
\cline { 3 - 5 } & & Normal & Prognathic & Retrognathic & \\
\hline 10-12 years & F\&\% & $2006(46.6 \%)$ & $24(.6 \%)$ & $2272(52.8 \%)$ & $4302(100.0 \%)$ \\
\hline 13-16 years & F\&\% & $2390(45.9 \%)$ & $40(.8 \%)$ & $2773(53.3 \%)$ & $5203(100.0 \%)$ \\
\hline Total & F\&\% & $\mathbf{4 3 9 6 ( 4 6 . 2 \% )}$ & $\mathbf{6 4}(.7 \%)$ & $\mathbf{5 0 4 5 ( 5 3 . 1 \% )}$ & $\mathbf{9 5 0 5}(\mathbf{1 0 0 . 0} \%)$ \\
\hline
\end{tabular}

Contingency Coefficient $=.014, \mathrm{P}$ value $=.386$ 


\section{Discussion:}

A population of same origin can show great variability in distribution of different type of malocclusion. ${ }^{8}$ In our survey, we observed children in the age group of $10-12$ years had $79.7 \%, 20.3 \%$ and $0.1 \%$ of Angle Class I, Class II and Class III malocclusions respectively which is similar to the findings with Usha Mohan Das ${ }^{9}$ and Antanas et $\mathrm{al}^{10}$. Children of $13-16$ years showed $78.8 \%, 21.1 \%$ and $0 \%$ of Class I, Class II and Class III malocclusions respectively which are in agreement with the studies of Profitt et al ${ }^{11}$, Grew et $\mathrm{al}^{12}$, Steigman et al ${ }^{13}$ and Jacob and Mathew ${ }^{14}$

Crowding was observed to be $50 \%$ in children of 13-16 years in our study which is in correspondence with the studies of Thilander et a ${ }^{15}$ and Gardener and Valiathan ${ }^{16}$. We found increased over-jet in $26.3 \%$ of the children with 13-16 years which is similar to the results of Antanas and Kristina ${ }^{10}$ and Bharadwaj et al ${ }^{17}$. Deepbite is reported to be $57 \%$ in our study but some of the studies have shown lesser prevalence ${ }^{18,19}$. The extreme of variation in the prevalence of may be due to the differences in methodology of recording the traits of malocclusion.

Ackermann- Proffit classification of malocclusion was used in the study to record the severity of malocclusion which is not generally used in any of the prevalence studies. This classification overcomes the limitations of the Angle system. Malocclusion is recorded in all the three planes of space (i.e, sagittal, transverse and vertical planes).

In our survey we have recorded the prevalence of malocclusion in school children of 10-12 years and 13-16 years which helps the clinicians and the specialists to diagnose the condition, plan the treatment needs and render the service. The outcome of the survey will be useful to the Community, Dental professionals and to NGO's to provide treatment to the needs and to further increase the awareness about orthodontic treatment in the school going children of Karnataka state.

\section{CONCLUSION}

The following conclusions were drawn from the present survey.

a. The prevalence of malocclusion reported in children of $10-12$ years were $51.9 \%$ of crowding, $7.8 \%$ of midline diastema, $17.5 \%$ of cross-bite, $26.3 \%$ of increased overjet and $56.6 \%$ of deepbite.

b. The prevalence of malocclusion in children of $13-16$ years were $40 \%$ of crowding, $4.8 \%$ of midline diastema, $18.2 \%$ of cross-bite, $27.4 \%$ of increased overjet and $56.3 \%$ of deepbite.

\section{Acknowledgements}

We thank the school authorities and the children for their cooperation in conducting the survey.

\section{REFERENCES}

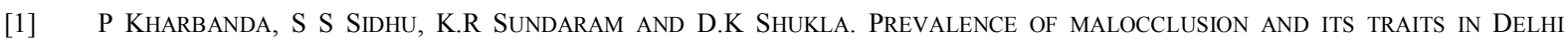
CHILDREN. JIOS 1995; JULY: 26 (3), 98-103.

[2] Miglani DC ET AL. EPIDEMIOLOGICAL STUDIES OF DENTAL DisORDERS AMONGST VARIOUS AGE GROUPS IN THE CITY OF MADRAS. JN INT COLL DENT 1965;3: 52.

[3] ARYA BS. ASURVEY OF MALOCCLUSION; EPIDEMIOLOGIC AND DIAGNOSTIC CONSIDERATIONS. J IND ORTHOD SOC 1976; 8: $15-28$.

[4] DINESH RB, ARNITHA HM, MUNSHI AK. MALOCCLUSION AND ORTHODONTIC TREATMENT NEED OF HANDICAPPED INDIVIDUALS IN SOUTH CANARA, INDIA. INTERNATIONAL DENTAL JOURNAL. 2003;53(1):13-8. EPUB 2003/03/26.

[5] Usha Mohan Das, Venkatsubramanian and Divya Reddy. Prevalence of Malocclusion among School Children in Bangalore, India. International Journal of Clinical Pediatric Dentistry 2008; September-December 1(1):10-12.

[6] KM Shivakumar, GN Chandu, MD Shafiullac. Severity of Malocclusion and Orthodontic Treatment Needs among 12- to 15-YearOld School Children of Davangere District, Karnataka, India. Eur J Dent 2010; 4:298- 307.

[7] 7.James L. Ackerman and William R. Proffit. The characteristics of malocclusion: A modern approach to classification and diagnosis. Am J Orthod 1969; 56: 5, 443- 454.

[8] M. O. SayinandH. T"urkkahraman, "Malocclusion and crowding in an orthodontically referred turkish population," Angle Orthodontist, vol. 74, no. 5, pp. 635-639, 2004.

[9] Usha Mohan Das, Venkatsubramanian, Divya Reddy. Prevalence of malocclusion in school children in Bangalore, India. International Journal of Clinical Pediatric Dentistry 2008; 1(1):10-12.

[10] Antanas Šidlauskas and Kristina Lopatienè. The prevalence of malocclusion among 7-15-year-old Lithuanian schoolchildren. Medicina (Kaunas) 2009; 45(2). 147-152

[11] W. R. Proffit and H. W. Fields, Contemporary Orthodontics, Mosby, St. Louis, Mo, USA, 2007.

[12] John M. Grewe, Jaroslav Cervenka, Burton L. Shapiro, and Carl I. Witkop, Jr. Prevalence of Malocclusion in Chippewa Indian Children. Journal of Dental Research. March-April 1968; Vol 47:No. 2, 302-305.

[13] Steigman, M. Kawar and Y. Zilberman. Prevalence and severity of malocclusion in Israeli Arab urban children 13 to 15 years of age. AJO-DO 1983; Oct (337-343).

[14] Jacob P.P and Mathew C.T. occlusal pattern study of school children [12-15 years] of Trivandrum city. Journal Indian Dental Association 1969; 41: 271-274.

[15] Thilander B, Pena L, Infante C, Parada SS, de Mayorga C. Prevalence of malocclusion and orthodontic treatment need in children and adolescents in Bogota, Colombia. An epidemiological study related to different stages of dental development. European journal of orthodontics. 2001;23(2):153-67. Epub 2001/06/12.

[16] Gardener J.H, Valiathan A. A survey of malocclusion and orthodontic treatment needs in South Canara. J Indian Orthod Soc; 1990:21;1-9. 
[17] V K Bharadwaj, K L Veeresh and K R Sharma. Prevalence of malocclusion and orthodontic treatment needs among 16 and 17 year old school going children in Shimla city, Himachal Pradesh. Indian Journal of Dental Research 2011; 22; 4, 556-560.

[18] O P Kharbanda, S S Sidhu, K.R Sundaram and D.K Shukla. Prevalence of malocclusion and its traits in Delhi children. JIOS 1995; July: 26 (3), 98-103.

[19] Chuckwudi Ochi Onyeaso. Prevalence of malocclusion among adolescents in Ibadan, Nigeria. AJO-DO 2004; 126: 604-7. 